\title{
10
}

\section{Fishers, Boats and Dredges: Great Moon Bay}

The dispute over Great Moon Bay had brought the issue of dredging into the foreground. And, in comparison with Bankstown Council later at Little Salt Pan, Hurstville Council pushed far harder to dredge the river and 'reclaim' low-lying land. While the issues of mangroves and saltmarsh were just one of the points of conflict in the dispute with Bankstown Council over Little Salt Pan Creek, this was not the case in the series of disputes with Hurstville and, later, with Kogarah Council, where mangroves became the centre of attention. The first of these disputes the campaign, beginning in 1962, to stop the dredging of the Great Moon Bay - also made visible the wider ecology of mangroves, showing the threatened areas to be not only the visible saltmarsh and mangroves but also the underwater seagrass beds.

The Great Moon Bay conflict showed the divergence of the interests of the longer-established residents with the newer or more affluent residents. The longer-established residents who lived on the more industrialised upper estuary from Liverpool down to Peakhurst, were predominantly working class or lower income and, most importantly, they fished for food as well as for recreation. They might fish from the bank or from rowboats or small 'tinnies' with low-powered engines. At least some of those residents who lived on the downstream reaches, from Oatley, Como and Sylvania in newer blocks, tended to be more affluent and middle class, often professionals and usually more securely employed. The residents who had formed themselves into the Georges River Oyster Lease Protest Association had unashamedly advertised themselves as owning 'exclusive' 
waterfrontage blocks. They not only owned more expensive land but also more often owned the new technology of private cars and powerboats, which they raced along with water skiers.

'Reclamation' - the 'rescuing' of low-lying land to make it into 'real' dry land - was an old idea, but it could not happen on its own. The material to fill in the low-lying land had to come from somewhere. The Little Salt Pan Creek dispute was focused on the land that was to be 'reclaimed' or filled in. It was not uncommon for this infill to be formed by dumping garbage into the area to be 'reclaimed' and this was certainly the case in areas like Little Salt Pan.

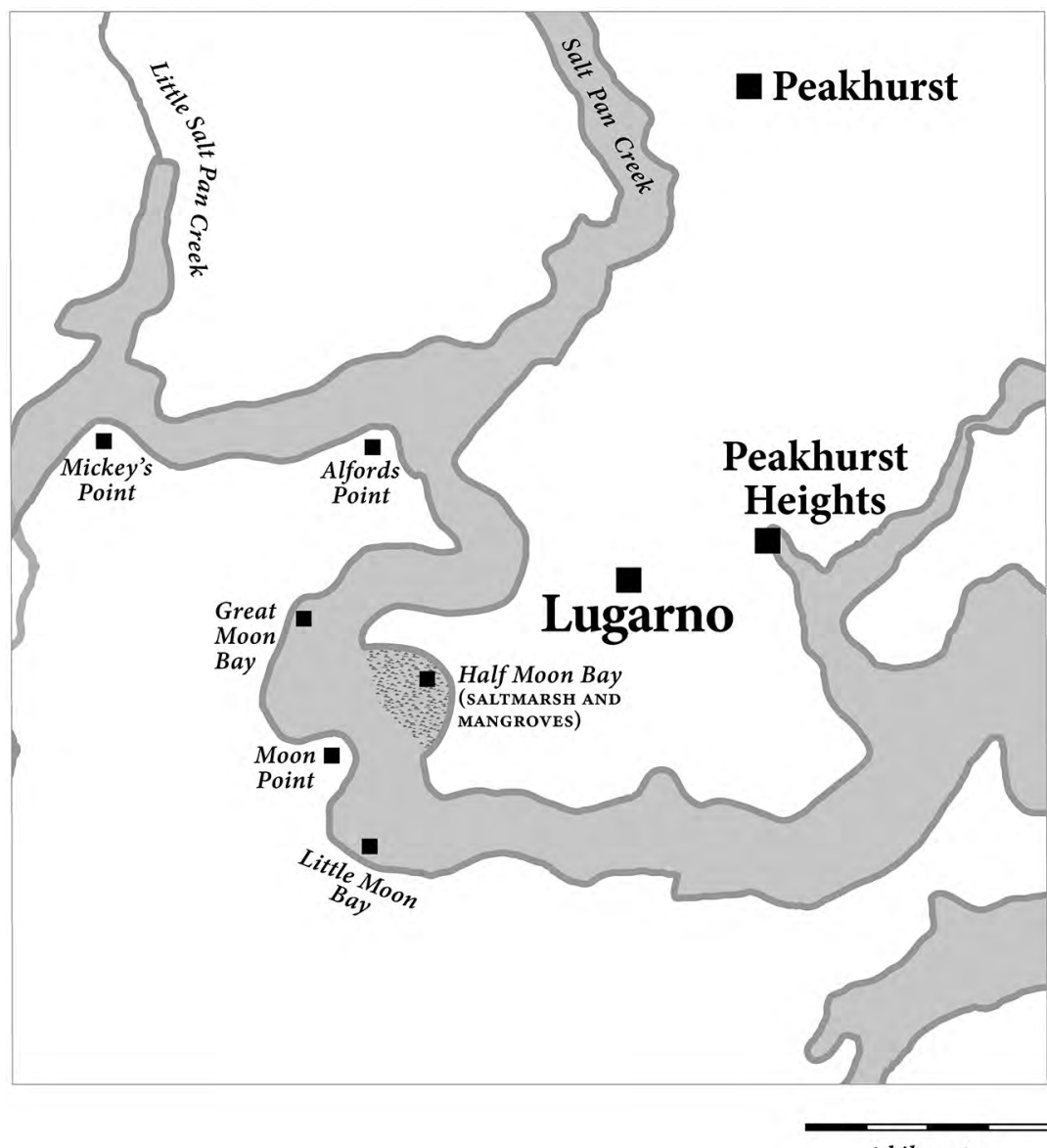

1 kilometre

Map 10.1: Lugarno and the Moon bays.

Cartography: Sharon Harrup. 


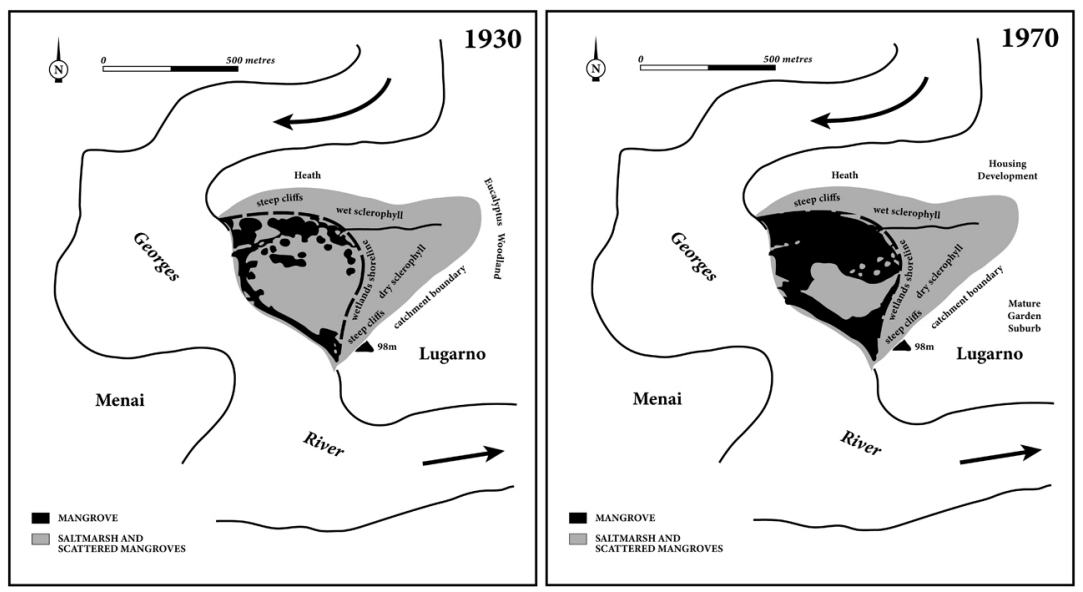

\section{Map 10.2: Mangrove expansion at Half Moon Bay.}

Maps redrawn for this volume with permission from Haworth (2003). Cartography: Sharon Harrup.

The other way to gain landfill - and often the preferred way in the years before the garbage explosion - was to dredge the bed of the river. The geological shift that had depressed the Cumberland Plain relative to the Blue Mountains to the west and the Woronora Plateau to the east had diverted the Georges River from its original northward path to be eventually captured by a stream that channelled the waters eastward to what became Botany Bay. Extensive quantities of sediment were deposited where the highland river met the lowlands of the Cumberland Plain around Chipping Norton and Milperra. Dredging the bed of the middle of the estuary therefore offered excellent clean sand for building. The councils along the river held the rights to extract royalties from commercial dredging companies that tendered to dredge. The three councils in the Georges River National Park Trust - Sutherland on the southern shore and Bankstown and Hurstville on the north - passed this royalty fee over to the National Park Trust, which used it - with additional contributions from the councils - to fund the improvements they made to the national park like toilets, picnic areas and reclamations.

But dredging the edges of the river and dumping the silt onto surrounding land to 'reclaim' it brought acid sulphate soils to the surface. The contamination arose not only from whatever had leached down into the waters from the area's factories, like the Union Carbide battery makers on Salt Pan Creek, but also from the chemical interactions of the bacteria on aquatic vegetation. Seagrass and mangrove roots interacted with the saline waters of the creeks as sea levels rose and fell over millennia, 
forming and trapping toxic acidic chemicals in sediments that, when disturbed, released them, often with deadly effects on the environment. ${ }^{1}$ Although this was not well understood in 1966, there were other problems with the dredging that quickly emerged.

Just like reclamations, dredging had not been considered a problematic issue in the period prior to World War II (WWII). But rising population and industrialisation after WWII seemed to threaten riverside access. This was what had led troubled residents like Alf and Eileen Stills (whose brothers were commercial fishermen on the Georges River) and George Jacobsen to campaign for the Georges River National Park in the 1950 s and, even though the trust was dependent on dredging royalties, there were members of the campaign group who, as fishing people, found dredging the riverbed to be a problem as well.

The Georges River National Park Trust had focused most of its 'improvements' on the areas of the national park within the Bankstown Council span of the river, from East Hills to Picnic Point and, notably, the Yeramba Lake artificial wetland, created by sealing the inlet off from the main river and 'improving' it by allowing freshwater run-off to fill the inlet and turn it into what, the trust congratulated itself, was a far better and more 'natural' freshwater wetland. The next proposal was the dredging of the Moon bays - a series of bends in the river just south of the mouth of Salt Pan Creek, between Illawong on the west and Lugarno on the east. The river bends were named as two bays - Great Moon Bay and Little Moon Bay - and were separated on the Illawong side by Moon Point (see Map 10.1) The trust had, since 1962, nurtured a plan to use the dredged material to fill low-lying areas at Mickey's Point and Alfords Point to create further flat grassed picnic and recreation areas as part of the national park. ${ }^{2}$

One of the local government bodies on the trust, Hurstville Council, thought it was a particularly good idea, because it would also enable it to fill the large mangrove and saltmarsh area on the Lugarno side, which was not in the national park. Both Great Moon Bay and Little Moon Bay were shallow, with the sandy bed clearly visible in aerial photographs, and were opposite swampland called Half Moon Bay, a mangrove and saltmarsh complex on the western side of the Lugarno peninsula.

1 Haworth, Baker and Flood, 'Predicted and Observed Holocene Sea-Levels'; Haworth, Baker and Flood, 'A 6000-Year-Old Fossil Dugong'; Baker, Haworth and Flood, 'An Oscillating Holocene Sea-Level'.

2 Hurstville Council Minutes, 1 March 1962, items 264, 265, 266 and 304, Local Studies Archive, Hurstville Library, Georges River Council Libraries. 
But, by 1967, another motive for Hurstville Council was apparent. As ownership of cars increased, more higher-cost subdivisions had been opened with river frontages, such as those at Padstow Heights overlooking Little Salt Pan Creek, which brought in higher rates to the council. Ownership of - or the aspirations to own - powerboats or ocean-going yachts was similarly increasing. The more affluent residents in the Hurstville area, from downstream bays like Oatley, were eager to increase their access to deeper quiet waters for mooring boats or to deeper channels with lower speed limits so their powerboats could take part in the new sport of water skiing. Both added to the motivations of Hurstville Council to dredge the Moon bays in order to deepen the channel, which lay on the western, or Illawong, side of the river, allowing greater access - and speed - for the powerboats owned by the residents downstream.

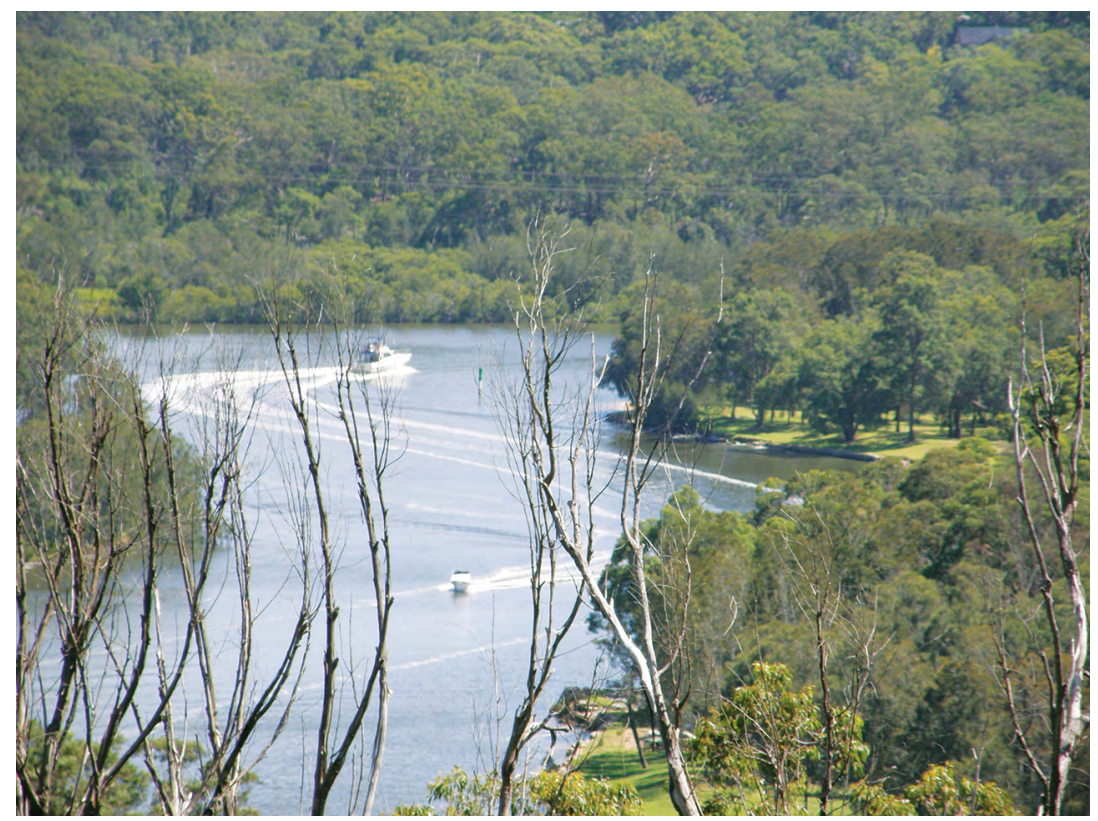

Figure 10.1: Speedboats on the Georges River.

The demand for dredging arose because of the pressure of rising numbers of powerboats on the lower Georges River. Photographer: Heather Goodall.

This raised the legal problem of the management of the waterways. The land beside the river - whether in public or private hands - was managed by local government and in the care of the state Department of Lands. Waterways, however, were technically under the control of the Maritime Services Board, particularly waters that were navigable and used 
by any types of shipping. Yet councils managed development on land all along the river, and they, as well as bodies like the National Park Trust, benefited from the profits from dredging royalties. As we have also seen, the New South Wales Department of Agriculture, through its Fisheries Branch, was the lessee for oyster leases. This legal complexity ensured that the National Park Trust and Hurstville Council needed the approval of the chief secretary to proceed with the dredging plan.

In December 1966 Sutherland Shire Council took the independent step of calling for an investigation into the conditions of the river. A member of the Georges River National Park Trust, Sutherland Shire was back under Labor Party control after a period of conservative dominance and had environmentally sympathetic councillors in key positions. One was Arthur Gietzelt, now shire president and a tenacious defender of the Royal National Park, although he was dismissive of the Georges River bushland. Kevin Skinner ${ }^{3}$ was chair of the Sutherland Shire Parks and Playgrounds Committee, which had also demonstrated its support for the Royal National Park as well as increasing the number of playing fields in the shire. The shire asked the Fisheries Branch to conduct a survey into the Georges River waterways to inform the projects of the three trust councils regarding the effects of dredging in the Georges and Woronora rivers and at Port Hacking. In announcing the survey, Kevin Skinner took the extraordinary step of breaking ranks with the other two Georges River National Park Trust councils, Bankstown and Hurstville, who were at that same time eagerly proposing major reclamation projects:

The Council has a responsibility in administering the waters of the Sutherland Shire ... The survey would guide the Council in any future applications for waterfront development or reclamation.

Because of conflicting views on dredging it was essential that a policy be formed.

The survey is necessary for the development of the river. ${ }^{4}$

3 Cr Kevin Skinner (ALP) (councillor 1962-87), a plumber by trade, was, for many years, chairman of the Parks and Playgrounds Committee, during which time more than 60 ovals and recreation areas were developed.

4 'Survey Planned for Waterways', St George and Sutherland Shire Leader (hereafter Leader), 14 December 1966, 11. 
Just like Kevin Howard, the Bankstown health inspector involved in the Little Salt Pan dispute, Skinner drew on the new principles of ecology as the Fisheries Branch biologists and others had been suggesting.

As the Sutherland Shire invitation demonstrated, the Fisheries Branch had become very active in outreach over the 1960s, carrying the new science of ecology to local resident groups. Skinner, Howard and local fishers were increasingly referring to emerging approaches that considered not individual species but, rather, the interactions between living creatures, including plants, insects and animals, in ways that facilitated both change and stability. This information was penetrating widely through the community in this period and it is as evident in Skinner's announcement in December 1966 as it was in Howard's memories of the period across the whole decade. ${ }^{5}$ There was much complex information in this new input, but there was one strand in particular that offered a new way to represent mangroves, a new metaphor - as protective and nurturing spaces for young fish.

The Fisheries Branch had been established in 1962 within the New South Wales Chief Secretary's Department. Heading it was Don Francois, a Canadian who had come to Australia first in 1958 to undertake research then, after completing his doctorate, had returned to take up the role of senior Fisheries biologist in the newly established Fisheries Branch. Francois was not a 'nativist' in that he did not believe that only native species should be protected. His interest was instead in fishing people. Although he strongly encouraged research into native species and the restocking of rivers with natives, he also introduced Atlantic salmon, eventually used in Tasmania as a resource for sport fishing as well as table fish. ${ }^{6}$ One of the Fisheries' senior biologists, W. B. Malcolm, who gave evidence before the Senate Select Committee, addressed many local groups as well as lead a major inquiry into the state of the Cooks and Georges rivers in 1969.7 Even earlier, in the mid-1960s, Francois was encouraging his staff to give talks to local groups like the Oatley Flora and Fauna Society (OFF).

\footnotetext{
5 Howard, interview.

6 James Halliday, 'Quietly Flows the Don', Australian, 14 March 2011; Australian Society of Fish Biology, 'Don Francois', accessed 4 February 2021, www.asfb.org.au/don-francois.

7 'Exhaustive Pollution Tests Soon', continued 'River Test for Pollution', Bankstown Torch, 20 August 1969, 1, 3; Editorial, Bankstown Torch, 20 August 1969, 2. Fairley, Being Green, 31.
} 


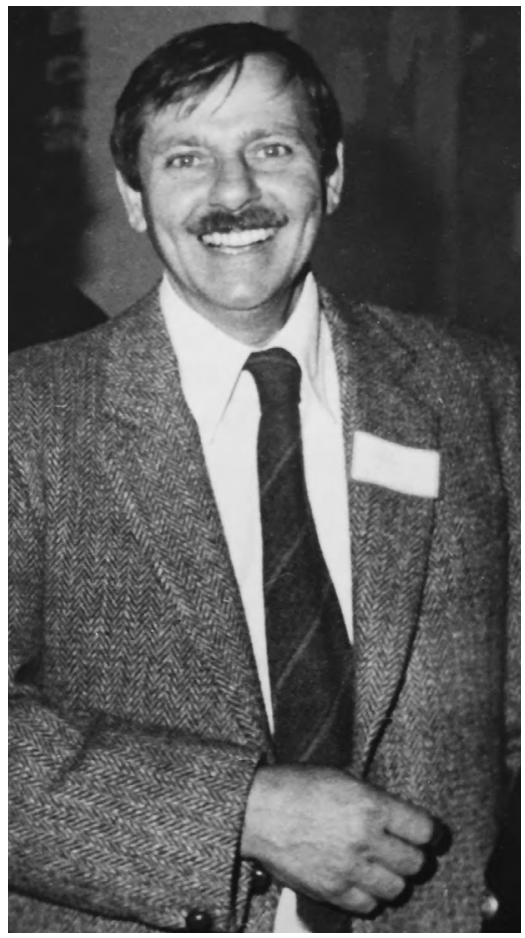

Figure 10.2: Dr Don Francois, first director of New South Wales Fisheries.

Don Francois was a fearless defender of aquatic habitats. He gave tireless support to Georges River fishing people, community activists and environmental campaigners. This photograph, taken in the mid-1970s, was one he liked, framed and gave to his daughters. Courtesy of Rachel Francois.
This Oatley group, introduced in the previous chapter, was composed of interested local people who focused on self-education about the native bush of the area. They invited expert speakers to their regular meetings, hearing from Francois, Malcolm and others. ${ }^{8}$ Although their polite advocacy had achieved little by the later 1960s, their regular meetings had brought about fruitful contacts with experts and concerned citizens who were to play increasing roles in the disputes of the coming years.

Francois himself became personally involved in the dispute over the dredging of the Moons, explaining to the trust and to the chief secretary that the two Moon bays were important precisely because the shallow bed of the river grew extensive beds of Zostera seagrass. The Zostera offered crucial habitat for whiting, one of the preferred catches for fishers along the river, and it was this invaluable resource that was being put at risk.

Francois's role could not have been effective had there not been a large proportion of the population who enjoyed fishing, were therefore knowledgeable about the bed of the river and were interested in protecting fish habitats. Recreational fishing had been an important source of knowledge and motivation for Kevin Howard in his support for the government analyst, Ernest Ogg's recommendation to close the river to both swimming and fishing in 1962, for the Little Salt Pan Creek campaign and then in his decision to undertaken further tertiary study

8 See Fairley, Being Green, a history of OFF, published online by OFF. 
in ecology. ${ }^{9}$ Local fishing people were responsive to the information that Don Francois and W. B. Malcolm conveyed as they built up a case to protect the fish in the riverine environment in ways that were less apparent in relation to other creatures like birds in this area.

Migratory birds were the focus of the Ramsar agreement, discussed in the previous chapter, and birds were the focus of the Australian treaty with Japan soon after..$^{10}$ The extensive Kelso Swamp on the Georges River near Milperra is remembered to have hosted vivid birdlife up to the 1950s, and there was some input into river environment protection campaigns further downstream about birdlife from nature study schoolteachers. In Mortdale, for example, in the 1940s, Robert Haworth has remembered that Mortdale Boys Public won the 'hotly contested' Gould League bird whistling competition year after year:

We went out with or without teachers to a promising bit of bush, and waited quietly for birds to appear and sing, the rarer the better - [these were] big tough boys who also played rugby league. ${ }^{11}$

Yet by the 1960s, when the Moon bays in the river and Half Moon Bay, the swamp on Lugarno, were all threatened, much habitat had already been lost as the population had grown and subdivision had expanded so rapidly. ${ }^{12}$ Rather than birds, the sustained concern among Georges River residents further upstream about water quality was around fish and fishing, although hunting ducks and other birdlife had figured strongly in memories of growing up along the river, around Kelso Swamp and other swamplands, like Half Moon Bay. So the language of the campaign against the dredging of the Moon bays and the destruction of the Half Moon Bay swamp was around fish and aquatic life, not about birds.

Despite such concerns from local people and his own Fisheries Branch, Chief Secretary Eric Willis agreed early in 1967 to the application from the Georges River National Park Trust through Hurstville Council for the dredging of Great Moon Bay and the stretch of the river where Zostera was

9 Goodall, Cadzow and Byrne, 'Mangroves, Garbage and Fishing'.

10 Bino, Jenkins and Kingsford, 'Adaptive Management of Ramsar Wetlands'; Kingsford, 'Ecological Impacts of Dams', Kingsford, 'Conservation Management of Rivers'.

11 Robert Haworth, pers. comm., June 2020; Kass, Educational Reform, 170-74; Roberts and Tribe, The Gould League.

12 Molloy, The History of Milperra, 86. See Fairley, Being Green, for OFF talks by fisheries as well as by schoolteachers re birds. See single letter in the Leader, 25 September 1968, 42, regarding mangroves as habitat for birds. See Kass Educational Reform regarding nature study in schools and its significance in development of environmental awareness. 
most vulnerable. The trust's confidence that this proposal was underway added to its shock when, in July, the premier announced that the Georges River parklands would be stripped of their national park status and be demoted to a 'state recreation park', later a 'regional park'. The trust was alarmed not only by the loss of status and the denigration of their community resource as unworthy of the status of 'the nation', but also by the loss of funds to undertake more work. Nevertheless, it was sure that the Moons dredging would go ahead, gloating to the local press about winning the 'long fight with the Fisheries Department'. ${ }^{13}$ The trust had not counted, however, on the tenacity of Francois and the fishers of the Georges River.

Don Francois redoubled his efforts to persuade Eric Willis against dredging. Local fishing people were deeply concerned and Francois conveyed their angry protests as well. ${ }^{14}$ This time Francois had more success. Although Willis was a senior minister in the conservative Askin government, he was also a thoughtful and serious environmentalist, having worked as a geographer before standing for parliament. ${ }^{15}$ Over the next year, Willis considered carefully the arguments put to him by fishermen and the Fisheries Branch, supported by letters from local groups like OFF. ${ }^{16}$ Then, in November 1968, Willis withdrew his consent for the dredging.

In announcing his decision, Willis explained that he had been persuaded by the Fisheries Branch that the Zostera beds were indeed important for fish and he instructed the trust and Francois to investigate alternative sources of landfill material. ${ }^{17}$ Willis had not acted explicitly to protect the mangroves and saltmarsh, but had instead focused on the riverbed and the seagrasses - and the whiting and recreational fishers. Willis explained that he was responding to the science as well as to widespread community concerns about the swamp and the fishing. ${ }^{18}$

13 'Shock by Government: Bill Will Strip Park of Status', Leader, 4 January 1967, 13; 'Georges River Parkland Fights for Existence', Leader, 23 August 1967, 2; 'National Park Loses Status - and Finance', Bankstown Torch, 23 August 1967.

14 Denise Walsh, Georges River fishing family member, pers. comm., October 2019.

15 Elizabeth Willis (Eric Willis's daughter), interview. Eric held a double honours BA in history as well as geography.

16 'Oatley Park - Limekiln Bay', OFF News, January 1969, 3.

17 'Willis Opposes Dredging in Bay', Leader, 4 November 1968, 27.

18 'Oatley Park - Limekiln Bay', OFF News, January 1969, 3. 


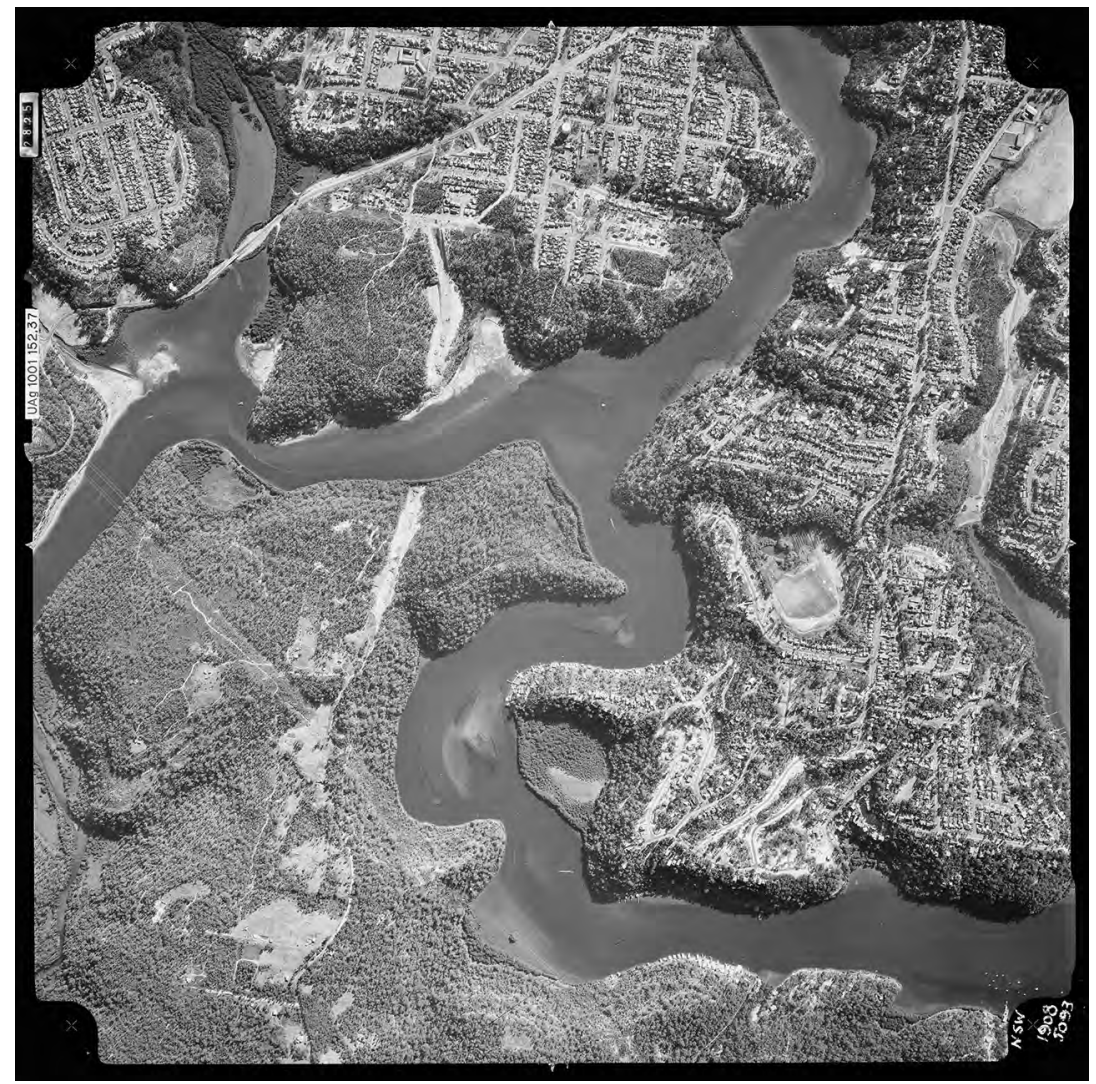

Figure 10.3: Aerial photograph of the Moon bays and Lugarno, 1 January 1970.

Illawong is on the Sutherland side of the river, lower left; the Moon bays and Half Moon Bay (mangroves and saltmarsh) are on the Lugarno peninsula, lower centre. This aerial photograph shows swamps also at Mickey's Point (centre left) and on both sides of where the road bridge was being constructed across Little Salt Pan Creek (upper left; see Chapter 4 for discussion of George Jacobsen's protest). Courtesy of Spatial Services, New South Wales Lands. Sheetname: Penrith, Film: 1908, Run R22, Frame 5093. Creative Commons.

In his letter to Hurstville Council, Willis stated:

The sands in the bay were renowned as a popular area for whiting. Dredging would have an adverse influence on the natural food for fish and be highly detrimental to amateur fishing. ${ }^{19}$

19 'Willis Opposes Dredging in Bay', Leader, 4 November 1968, 27. 
Hurstville Council aldermen were furious, setting up the conflict as one between people and the environment and demanding that Willis fund the additional costs:

Ald A.A. Lawrance (ALP) said he did not think it was the concern of Hurstville Council to provide spawning grounds for fish. 'But we do have to provide parks for the municipality.' Ald Lawrance said he wondered what excuse would be used next to stop the dredging ... 'When the council had discussed previously a commercial venture involving dredging in the area, Mr Willis' department had not been concerned about the effect on fish. We would be quite prepared to fill from somewhere else if $\mathrm{Mr}$ Willis is prepared to make up the financial difference. If he is so interested in the spawning of fish, he won't mind paying out the money. ${ }^{20}$

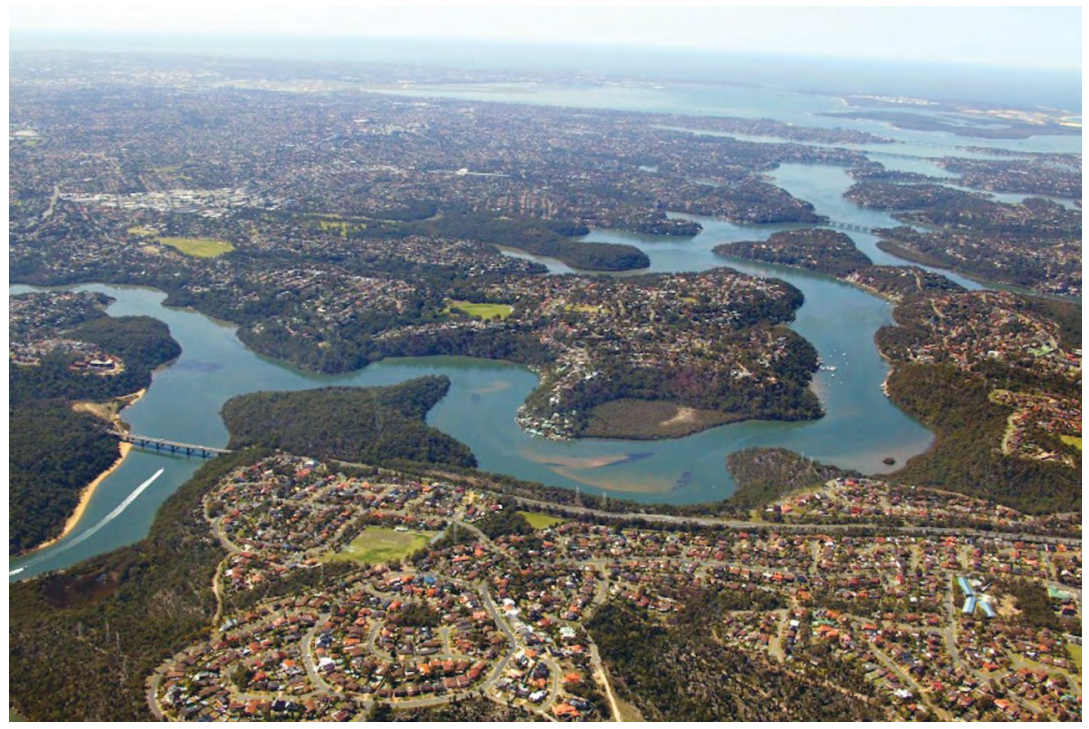

Figure 10.4: Recent aerial photograph, looking from Illawong in the lower foreground towards Botany Bay and the coast.

Salt Pan Creek is on the left, then Mickey's Point and Alfords Point, then the peninsula of Lugarno. The protected shallow riverbed of both Great Moon Bay and Little Moon Bay are clearly visible, as is Half Moon Bay, the mangrove and saltmarsh area on the western point of Lugarno peninsula. The bridge over the river at Alfords Point (on the A6) is on the left of the photograph, the Como rail bridge is in the middle distance and then, going downstream, Tom Ugly's Bridge (on the A1) and finally Tarren Point Bridge cross the river before it becomes Botany Bay just before Towra Point. Courtesy of AirviewOnline Pty Ltd. 
This text is taken from Georges River Blues: Swamps, Mangroves and Resident Action, 1945-1980, by Heather Goodall, published 2022, The Australian National University, Canberra, Australia.

doi.org/10.22459/GRB.2021.10 